\title{
Epidemiology of mycobacteria infections in Basilicata, Italy: 1999-2012
}

\author{
Leonardo Buono, Giuseppe Montesano
}

Madonna delle Grazie Hospital, Matera, Italy

\section{Summary}

This short note describes the epidemiology of mycobacteria related infection through laboratory data in the region of Basilicata (Southern Italy) over a period of 13 years from 1999 to 2012 . A total of 14,255 clinical specimens have been evaluated, showing 370 positive identification (84\% M.tuberculosis complex and 16\% non-tuberculosis mycobacteria).

\section{Introduction}

The availaibility of an efficacious laboratory diagnosis is the bottom line to achieve an effective control of mycobacteria related infections.

The Basilicata Region (Southern Italy) started in 1999 a specific regional project to implement a regional reference centre for diagnosis of mycobacteria infection in the Centro di Medicina Sociale per le Malattie dell'Apparato

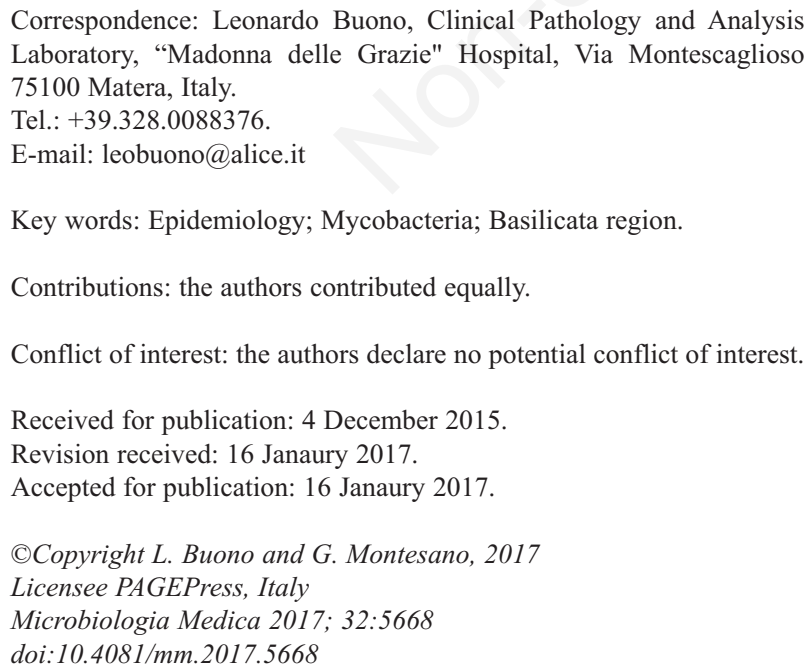

Key words: Epidemiology; Mycobacteria; Basilicata region.

Contributions: the authors contributed equally.

Conflict of interest: the authors declare no potential conflict of interest.

Received for publication: 4 December 2015.

Revision received: 16 Janaury 2017.

Accepted for publication: 16 Janaury 2017.

(C) Copyright L. Buono and G. Montesano, 2017

Licensee PAGEPress, Italy

Microbiologia Medica 2017; 32:5668

doi:10.4081/mm.2017.5668

This article is distributed under the terms of the Creative Commons Attribution Noncommercial License (by-nc 4.0) which permits any noncommercial use, distribution, and reproduction in any medium, provided the original author(s) and source are credited.
Respiratorio, ASL 4 of Matera. Later on, in 2002, this centre was transferred to the Ospedale Madonna delle Grazie of ASL 4 of Matera, This laboratory participated in many National diagnostic activities including the SMIRA (Studio Multicentrico Italiano Resistenze Antibiogramma - Italian Multicentric Study on Antibiogram Resistance) project and in the external quality control activities managed by ISS (Istituto Superiore di Sanità) $(1,8)$

This laboratory had since the beginning of its activity available the basic resources for the diagnosis, including microscopy, culture based tests alongside with the biochemical identification of species. Specific antimicrobial sensitivity tests and gene amplification were also available $(7,8,10,11)$.

The aim of this report is to describe the overall data collected over 13 years in Basilicata.

\section{Materials and methods}

From 1999 to 2012 a total of 14,255 samples of pathological materials were examined (Table 1). The microscopic examination and the culture tests were performed using standard methods (8). The gene amplification was carried out using a Strand Displacement Amplification (SDA) technology. This method was also used in samples of extra-pulmonary origin, even if aware that this technique is not completely validated of non respiratory specimens.

From 1999 to 2005 the identification of NonTuberculous Mycobacteria (NTMs) was outsourced to the reference Centre for Mycobacteria in Tuscany were a high-performance liquid chromatography (HPLC) was applied. From 2006 onward this diagnosis has been directly performed by $h s p 65$ gene sequencing $(9,10)$.

The antimicrobial sensitivity testing was determined for streptomycin (SM), isoniazid (INI), rifampicin (RMP) and ethambutol (ETB), using the proportion method on solid medium until 2007, and thereafter by using the MGIT liquid medium method (Becton, Dickinson and Company, Milan, Italy) $(4,13)$.

A total of 370 mycobacteria strains were isolated: 310 (84\%) belonged to the $M$. tuberculosis complex and 60 $(16.0 \%)$ to the group of non-tuberculous mycobacteria. In Tables 1 and 2 are summarized the results. The results obtained for NMTs are indicated in Table 3. 


\section{Results}

It is noteworthy that $M$. paraffinicum was isolated from one patient that has been previously treated for tubercolosis and that although treatment with second-line pharmaceuticals was maintained, M. paraffinicum was still isolated over at least 4 years after the stop of the specific tuberculosis therapy.

Three of the NTMs isolates were from foreigners citizens arrived in Italy less than 6 months before this diagnosis: two were not typeable and one was a $M$. abscessus isolate. M. porcinum/septicum was isolated from a patient suffering from pulmonary cancer $(6,12)$.
The AST data obtained over the 13 years of the study clealrly showed that $79 \%$ (n.245) isolates of M.tuberculosis complex were sensitive to the common therapeutic agents whereas only $21 \%$ (n.65) showed a variable degree of resistance. Only 3 isolates (all obtained from respiratory biological samples were classified as MDR according to the current definition $(2,3,5)$.

\section{Conclusions}

In conclusion, it can be stated that the centralization of the laboratory diagnosis for the mycobacteria related,

Table 1. Origin of samples.

\begin{tabular}{lcc} 
Type of sample & N. & $\%$ \\
Sputum, bal, bas aspirates gastrico & 9463 & 66.3 \\
Genito-urinary materials & 1886 & 13.2 \\
\hline Liquor & 184 & 1.3 \\
Cavitary fluids: pleu., peric., perit., synov. & 2307 & 16.2 \\
\hline Purulent materials and aspirates & 262 & 1.8 \\
Miscellaneous materials (biopsies, blood, faeces) & 153 & 1.1 \\
Total & 14,255 & 100 \\
\hline
\end{tabular}

Table 2. Mycobacterium tuberculosis complex isolated in various materials (in parenthesis the number of isolated strains from NotItalian patients).

\begin{tabular}{|c|c|c|c|}
\hline Pathological materials & $\begin{array}{l}\text { Autochthonous } \\
\text { (foreign), } \mathrm{n} \text {. }\end{array}$ & N. & $\%$ \\
\hline Respiratory material & $194(41)$ & 235 & 75.8 \\
\hline Genital-urinary material & $24(1)$ & 25 & 8.1 \\
\hline Liquor & $12(0)$ & 12 & 3.9 \\
\hline Cavitary fluids ( pleu., peric., perit., synov) & $11(4)$ & 15 & 4.8 \\
\hline Material and aspirates (gluteal pus from psoas abscess, intervertebral lymphoglandular and scrotal) & $12(3)$ & 15 & 4.8 \\
\hline Biopsies & $5(1)$ & 6 & 1.9 \\
\hline Various materials (faeces and blood) & $2(0)$ & 2 & 0.6 \\
\hline Total & $260(50)$ & 310 & 100 \\
\hline
\end{tabular}

Table 3. Non-tuberculosis mycobacteria species and number of isolated strains.

\begin{tabular}{|c|c|c|c|}
\hline M. avium & 2 & M. kumamotonense & 1 \\
\hline M. chelonaelabscessus & 5 & M. mucogenicum & 1 \\
\hline M. fallax & 1 & M. paraffinicum & 1 \\
\hline M. fotuitum & 1 & M. paratuberculosis & 2 \\
\hline M. gordonae & 5 & M. porcinum/septicum & 3 \\
\hline M. houstonense/terrae & 1 & M. thermoresistibile & 2 \\
\hline M. inje & 1 & M.xenopi & 24 \\
\hline M. intracellulare & 3 & NOT typeable NTMs & 2 \\
\hline M. kansasii & 5 & Total strains isolated & 60 \\
\hline
\end{tabular}


besides the possibility top draw a very comphensive epidemiological picture, has enabled to observe the presence of NTMs not identifiable by biochemical techniques giving evidence about the circulation of these bacteria also in Basilicata region.

\section{References}

1. American Thoracic Society. Level of laboratory services for mycobacterial diseases. Am Rev Resp Dis 1983; 128:21.

2. Buono L, Mazzarone R. Resistenze micobatteriche rilevate in provincia di Matera (osservazioni relative al quadriennio 1977-80). Arch Monaldi 1981;36:131-41.

3. Buono L, Montesano G. Resistenze micobatteriche e farmacoterapia. Considerazioni su una casista. Lotta contro la Tubercolosi e Malattie Polmonari Sociali 1991;61: 444-48

4. Canetti G, Rist N, Grosset J. Measure de la sensibilitè du bacille tuberculeux aux drogues antibacillaires par la méthode des proportions. Rev Tuberc Pneumol 1963;27: 217-72.

5. Fattorini L. Migliori GB, Cassone A. Extensively drgresistant (XDR) tuberculosi: an old andnew threat. Ann Ist super Sanità 2007;43:317-9.
6. Grottola A, Messinò M, Apice $M$, et al. Identification of nontuberculous micobacteria using commercial DNA probes and gene sequencing. Microb Med 2009;24:230-2.

7. Kubica GP, Kent PT. Public health of Mycobcteriology: a guide for the level III Laboratory. Atlanta: US Department of Healt and Human Servces; 1985. pp 159-189.

8. Mandler F, Passerini Tosi C, Scarparo C, Piersimoni C. Proposta di linee-guida per la diagnostica della tubercolosi. Microbiol Med 1999;14:313-30.

9. Mazzarelli G, Rindi L, Piccoli P, et al. Evaluation of the BDProbetec ET system for direct detection of Mycobacterium tubercolosis in polmonary and extrapulmonary samples: a multi center study. J Clin Microbiol 2003;41:1779-82.

10. Talenti A, Marches F, Bald M, et al. Rapid identification of mycobacteria to the species levelby pollymerase chain reation and restrition enzyme analysis. J Clin Microbiol 1993;31:175-8.

11. Tortoli E, Bartoloni A. High-performance liquid cromatography and identification of mycobacteria. Rev Med Microbiol 1996;7:207-19.

12..Tortoli E. Clinical manifestations of nontuberculous mycobacteria infections. Clin Microbiol Infect 2009;15: 906-10.

13. Tortoli E, Piersimoni C, Scarparo C, Cirillo DM. Micobatteriologia clinica. Pavia: Edizione Selecta Medica; 2008 . 